\title{
Szenvedélybeteg-ellátás a Covid-19-járvány időszakában: Interjúk a pécsi Addiktológiai Ambulancia, az Alternatíva Ifjúsági Iroda és a Tér Közösségi Szolgálat munkatársaival
}

Providing services for persons with substance use disorder during the COVID-19 pandemic: Interviews with professionals working at Outpatient Drug Treatment Centre, Alternative Youth Service and Tér Community Service (Pécs, Hungary)

\section{MADÁCSY JÓZSEF}

\begin{abstract}
Madácsy József: Pécsi Tudományegyetem, Bölcsészettudományi Kar, Társadalmi Kapcsolatok Intézete, Közösségi és Szociális Tanulmányok Tanszék; madacsy.jozsef@pte.hu

József Madácsy: University of Pécs, Faculty of Humanities, Institute of Social Relations, Department of Community and Social Studies; madacsy.jozsef@pte.hu
\end{abstract}

Az alábbi két interjú egy több interjúból álló sorozat része, amelyek a pécsi Integrált Drogterápiás Intézet (INDIT) Közalapítvány néhány intézményének munkatársaival készültek, arról, hogy miként müködtek, milyen tapasztalatokat szereztek a Covid-19-járvány időszakában érvényben lévő rendkívüli helyzetben.

Az első interjú 2020. május 26-án készült Kárpáti Tamás klinikai szakpszichológussal, akivel az ő szakmai vezetése alatt müködő Addiktológiai Ambulanciáról, illetve az ennek részeként futó MBT Ambulancia ${ }^{1}$ szolgáltatásról beszélgettünk. A szóba kerülő intézményi szolgáltatások az „elterelés”, ${ }^{2}$ a gyógyszeres kezelés, illetve a terápiás és konzultációs folyamatok voltak.

A következő interjú 2020. június 5-én készült, ekkor a szociális munkás, közösségszervező, addiktológiai konzultáns, szociálpolitikus és szociálpolitikai szakértő Máté Zsolttal, az Alternatíva Ifjúsági Iroda és a Tér Közösségi Szolgálat szakmai vezetőjével beszélgettem az általa vezetett intézményekről. Az Alternatíva Ifjúsági Iroda kapcsán olyan szolgáltatások kerültek szóba, mint az iskolai megkereső munka, a konzultációk és a kortárs képzés, illetve mindezek mellett a „tartalomelöállítás” háttérmunkálatai, a Tér Közösségi Szolgálat kapcsán pedig az intézményben zajló konzultációk, illetve a prostituáltaknak nyújtott utcai megkeresőprogram.

A további interjúk megjelenése a következő lapszámban várható.

\footnotetext{
${ }^{1}$ Az MBT a Mentalization Based Therapy, azaz mentalizációalapú terápia rövidítése.

${ }^{2}$ Csekély mennyiségben elkövetett kábítószerrel való visszaélés vétsége esetén a büntetőeljárás helyett - a Büntető Törvénykönyvben meghatározott feltételekkel - hat hónapos kábítószer-függőséget gyógyító kezelésben, kábítószer-használatot kezelő más ellátásban vagy megelöző-felvilágosító szolgáltatásban való részvétel választható (Btk. 180.§), melyet a szakmában gyakran „,elterelés”-nek neveznek.
} 


\section{Interjú Kárpáti Tamással}

- Mióta kitört a járvány, mik a tapasztalatok itt, a „Drogambulancián”? Milyen kérdések és dilemmák merültek fel, mik a föbb problémák vagy akár lehetséges elönyök? Egyszóval, hogyan értékelitek a helyzetet?

- Már viszonylag korán elkezdtünk átállni online-ra. Még mielőtt a mindenféle korlátozásokat bevezették volna, már akkor elkezdtünk afelé menni, hogy a kliensekkel próbálgassuk ezt az online távterápiás lehetőséget. Ezt megelőzően az volt a tapasztalat például az elterelés kapcsán, hogy az utóbbi években sokan voltak olyanok, akiket Magyarországon lekapcsoltak, és elterelést kaptak, de külföldön dolgoztak. Kérdés volt, hogy az elterelés ilyen esetekben hogyan tud müködni. Eddig ez a távterápiás vagy a Skype-on történő elterelés jogszabályi lehetősége nem volt adott.

- Ez most teljesen elfogadott, hivatalosan, hogy az elterelés online formában történhet?

- Ez változott, igen, online formában is müködhet.

- Milyen tapasztalataitok vannak még?

- Az elterelés kapcsán például más változás is segítette a munkát. Korábban, ha egy hónapnál több idő maradt ki, akkor megszakadt az elterelés. Most hoztak egy erre vonatkozó rendeletet, hogy ez most nem érvényes a járvány ideje alatt. Szóval, ha egy páciens nem tud átállni onlinera, vagy valami ebben elakad, és kicsúszik ebböl a két találkozás közötti egy hónapos időszakból, akkor ez nem jelenti azt, hogy elölről kellene kezdenie az elterelést. Vagy ugyanúgy, ha valakinek ott tart az ügye, hogy már el kellett volna kezdenie az elterelést, de valami miatt nem tud elérni hozzánk, az sem jelentett problémát a járvány ideje alatt.

- És más területeken mi történt?

- Kicsit általánosságban is, meg nálunk is az volt a tapasztalható többektöl, hogy ódzkodtak ettől az online történő beszélgetéstől, terápiától, konzultációtól, de aztán az volt a tapasztalat, hogy gyorsan át tudtak állni a kollégák is. Gördülékeny volt, a pácienseket is gyorsan át lehetett erre állítani. Pár olyan eset volt, ahol az Internet nem volt elérhető, vagy nem volt okostelefon és hasonlók. Velük hagyományos telefonon keresztül vagy mobilon kellett beszélni, de a többségük könnyen átállt ezekre az online formákra. Szóval időben elkezdtük szerintem, és így rugalmasan tudott reagálni a stáb is, meg a páciensek is.

A másik tapasztalat vagy dilemma az volt, hogy a kollégák között volt, akinek gyerekekkel kellett otthon maradnia, és voltak veszélyeztetettebbek, akiknek esetleg komolyabb problémája is lehetett volna, ha elkapják a vírust. Ezért ők teljesen online-ba költöztek, és otthonról dolgoztak, és voltunk mi, akik ügyeleti rendben kezdtünk el dolgozni az Ambulancián, ami azt jelentette, hogy online dolgoztunk többnyire, de lehetőséget biztosítottunk arra, hogy ha valami nagyon akut, személyes ellátási igény merült fel, akkor telefonos, e-mailes vagy az intézményi honlapon keresztüli bejelentkezés után személyesen is tudjon velünk találkozni a páciens. Az új páciensek előzetes bejelentkezésének rendszerét már korábban is használtuk, de a honlapon lévő online jelentkezési lap új, a krízisidőszakban végzett fejlesztésünk, ami nagyon jól bevált. Azt nem lehetett volna megcsinálni, hogy teljesen átállunk online-ra, egészségügyi intézmény vagyunk, szakellátást nyújtunk, egyszerűen kellett az, hogy be lehessen jönni az Ambulanciára, ha esetleg valamilyen akut eset van. Vannak, akik metadont kapnak, voltak olyanok, akiknek kellett a személyes kontakt - ha szuicid veszély vagy bármi ilyen felmerült, akkor az Ambulancia kertjében le lehetett ülni a pácienssel beszélgetni. Ami felmerült még az online konzultáció vagy terápia kapcsán, hogy volt, nem sok, nem számottevő 
páciens, aki paranoid volt, és azt mondta, hogy ő nem hajlandó Interneten keresztül beszélni. Két-három embert érintett ez összességében, és velük történt személyes konzultáció, időszakosan. De minimalizálni igyekeztünk a személyes kontaktot - ha volt is, ennek azért volt egy protokollja: kézfertőtlenítés, maszk stb. Ezeket az óvintézkedéseket ilyenkor betartottuk, de többségében átálltunk online-ra.

Idővel az változott az ügyeleti rendben, hogy csináltunk két csapatot, hogy ha az egyik lebetegszik esetleg, az ellátás akkor is fenn tudjon maradni hosszú távon, mert akkor a másik csapat ott tud lenni. Az átállás így zajlott. A terápiás találkozások nagy részét - az egyénit és a csoportot is -, illetve a stábmunkát is átszerveztük az online térbe. Heti rendszerességgel volt esetmegbeszélőnk, és van még most ezen a héten is.

- Tudtok már valamit a korlátozások esetleges enyhitéséröl?

- Most még mindig ügyeleti rendszerben vagyunk, annyi változik, hogy a többgyerekes kollégánk vissza tud jönni, mert most már van iskolai gyerekmegörzés. Júniusban lesz stáb, és akkor megbeszéljük azt, hogyan állunk vissza ebből az ügyeleti rendszerből. Június közepén, szerintem, akkor fogunk visszaállni.

- Milyen tapasztalataitok voltak még?

- Védőfelszerelést szerettünk volna az ÁEEK-től [Állami Egészségügyi Ellátó Központ] kérni, de nem kaptunk, mert nem vagyunk kórházi intézmény, így a maszkot, fertőtlenítőt nekünk kellett próbálni beszerezni. Ebben is valahol időben reagáltunk, mert tudtunk még venni tíz maszkot az elején, a kézfertőtlenítő is kitartott végig. De hát ebből azért volt szorongás. Nálunk nem olyan nagy, mert kevés volt a személyes kontakt, de azért más intézményi egységeknél jóval erőteljesebben jelentkeztek a helyzetből adódó félelmek és szorongások.

Ami még tapasztalható volt, hogy a pszichiátrián ágyszámcsökkentés történt, átkerültek ágyak a covidos osztályokra, és ebből adódóan a pszichiátriai ellátás kapacitása elég behatárolt lett, ami azt jelentette, hogy csak nagyon-nagyon akut esetben volt arra lehetöség, hogy az osztályra felvegyenek valakit. Ebből a szempontból nehézség volt, vagy volt ebben is egy kis szorongás, hogy mennyire vagyunk magunkra hagyva e téren. Illetve tapasztaltunk olyat is, hogy jöttek - föleg az elején - új páciensek többen is a pszichiátria irányából, mert viszonylag gyorsan ki lettek rakva: felszaporodott kicsit a pszichiátriáról gyorsan felénk delegált pácienseknek a száma. De aztán nem volt ebből semmi konkrét probléma, ezek félelmek voltak, de aztán nem alakult úgy, hogy bárkit is be kellett volna utalni a pszichiátriai osztályra, esetleg nem vették volna fel - nem lettek ebböl zürök.

Magára az online térben való munkára is ki kellett dolgoznunk egy protokollt, hogy milyen szabályok mentén történjen az online terápia, vagy távterápia, vagy távkonzultáció, vagy elterelés. Kicsit ketté is szedem, de a kettő valamelyest össze is kapcsolódik, mert van a Drogambulancia, és van a Mentalizációs Ambulancia. A Drogambulancián kevésbé foglalkoztunk azzal, hogy minél biztonságosabb platformot találjunk az online beszélgetésre, de a mentalizációban ez egy fontos dolog volt, mivel rögzítjük az egyéni és a csoportterápiát is - ezért különösen fontos volt, hogy olyan applikációt találjunk, amivel ezt biztonságosan lehet megtenni. Ez fontos volt az MBT-nél.

Mind a Drogambulancián, mind az Mentalizációs Ambulancián egy protokollt dolgoztunk ki, ami a páciensek számára is nyilvánvalóvá teszi a kereteket, és megteremt egyfajta biztonságot az online téren keresztül is. Ha otthonról beszélgetnek a páciensek - a kollégák között is van, aki otthonról beszélget -, akkor ne pizsamában üljenek. Kamerával történjen a becsatlakozás, legalább az elején ne lehessen kamera nélkül vagy kép nélkül bekapcsolódni. Ez a csoportterápiában is fontos szempont volt. Talán ott még inkább. A 
járványidőszak elején az egyéni konzultációs folyamatokat és terápiákat állítottuk át online-ra, a csoportot azt félretettük. De aztán idővel a csoportot is elkezdtük megszervezni online, és az is így müködik.

Ebben a tapasztalat a páciensek részéről vegyes volt. Voltak páciensek, akik úgy élték meg ezt az egész karanténhelyzetet - például a szorongósabb páciensek -, hogy ez könnyebbség volt nekik, hogy nincsen annyi interakció, nincsen olyan nyomás rajtuk. De voltak olyanok is, akik nagyon nehezen viselték ezt a fajta izolálódást. Az megjelent, nem mindenkinél, de több páciensnél is megjelent azért, hogy az online beszélgetés nem ugyanolyan, mint a személyes találkozás, hogy azért ennek van egyfajta távolsága, vagy ez nem olyan hatékony az ő számukra. Ezzel kellett dolgozni, hogy mégis, hogy tudnak ebből erőt meríteni, vagy hogy tudnak ebben értelmet találni.

Az jó volt a gyógyszerfelírás, meg receptek kapcsán, hogy müködik az e-recept - ez sokat könnyített. Az is, hogy viszonylag időben reagált a minisztérium a finanszírozás kérdésére. Mert az elején nem volt tiszta, hogy mi alapján fogunk finanszírozást kapni. Az, hogy lecsökkent a páciensszám - olyan radikálisan különben nem csökkent le -, az tapasztalható volt: főleg az első időszakban kevesebb új jelentkező volt hétről-hétre, de úgy összességében a terápiás konzultációs óraszám nem csökkent le. De mégis ott volt a bizonytalanság, hogy a finanszírozás hogy lesz, ha lecsökken a páciensszám, mert finanszírozást a beavatkozások alapján kapunk. De bizonyos idő után kijött az a rendelet, hogy az elmúlt három hónap átlagfinanszírozását fogjuk megkapni, függetlenül attól, hogy aktuálisan mennyi pácienst látunk el. Egyébként, mivel nem volt radikális csökkenés a páciensszámban, a beavatkozások alapján meg tudtuk így is termelni azt a havi pontmennyiséget, ami a finanszírozáshoz kell. De azért a rendelet adott egy nyugalmat, nem kellett ezen görcsölni vagy szorongani, hogy miböl lesz a finanszírozásunk. Ezek voltak a könnyítések, amik segítették a munkánkat.

- Mi történt az intézményközi kapcsolatok, a delegálás terén? Mondtad, hogy eleinte tartottatok tôle, hogy a pszichiátriai ágycsökkentés okozhat fennakadást.

- De aztán nem okozott.

- Igen. És más intézményekbe való delegálással mi volt a helyzet?

- A rehabilitációs intézményekkel kapcsolatban voltak bizonytalanságok. Ehhez is idő kellett, amíg náluk kialakult a rehabokba való bekerülés menete. Ebben különbözőek voltak a rehabok országosan tekintve. Bezártak, de egy idő után volt, ahova két hét karantén vagy negatív teszt után lehetett felvételizni, de volt olyan rehab is, amelyik azt mondta, hogy az új bejövők elött bezár teljesen, amíg járvány van, addig nem vesznek fel új terápiásokat. Szóval volt ebben egy kis bizonytalanság. De aztán erre is viszonylag gyorsan tudott reagálni az ellátórendszer. A Nyírö bezárt szinte, de ez aktuálisan nem okozott olyan problémát, hogy nagyon akartunk volna valakit oda delegálni, és nem tudtunk.

- A páciensekkel kapcsolatban emlitetted, hogy különbözöképpen reagáltak az online kapcsolattartásra. Volt velük kapcsolatban más tapasztaltatok is?

- Gazdasági szempont, hogy a pácienseknél is tapasztalható volt, hogy bár nem vesztették el sokan a munkájukat, de azért volt ebben egy bizonytalanság: „Mi van, ha elvesztem a munkámat?”. Voltak páciensek, akik munkakeresésben voltak, és nem nagyon találtak munkát. Szóval azért az egzisztenciális szorongás is megjelent, és jelen volt az izolálódásnak a szorongása is, illetve a megfertőződéstől való félelem, és az, hogy „Mi van, ha tünetmentes vírushordozó vagyok, másokat megfertőzök, és ebből baj lesz?”. 
- Igen, ez érthető. Személy szerint a saját szakmai munkádat elönyök-hátrányok tekintetében hogy értékeled?

- Nekem nagyon izgalmas volt, kihívásnak éltem meg az online-ra átállást. Én azt tapasztaltam, hogy ez így tud müködni. Bokor Lászlónak - pszichoterapeuta, pszichoanalitikus, aki viszonylag sokat foglalkozott ezzel a témával - például most egy csomó írása jelent meg a neten, ami támpontot jelentett ahhoz, hogy hogyan dolgozzak, hogyan dolgozzunk. Ezek sokat segítettek, és ez tudott müködni. Persze nem lehet egy terápiát teljesen átrakni online-ba, időszakonként kell találkozni. Vagy az első találkozók jó, hogy ha személyesen történnek. Szóval igaz, hogy ez az időszak nagyon izgalmas, meg nekem nagyon inspiráló volt, azért ezt hozzá kell tenni mindenképpen.

Ami nehéz volt szerintem, hogy a rendkívüli helyzet nagyon nagy rugalmasságot igényelt: azért az tapasztalható volt, hogy kevés az információ, nehéz eldönteni, hogy milyen információ az, ami hiteles, vagy amire érdemes tényleg hallgatni. Rugalmasnak kellett lenni, hétről-hétre kellett update-elni azt, hogy hogyan alakulnak a dolgok, ehhez képest mi hogy alakítsuk a terápiás müködésünket, az Ambulancia müködését. Nekem ambulanciavezetőként figyelni kellett erre hétről-hétre, ami plusz energiát igényelt. De az jó volt, hogy a kollégák is azért tájékozódtak, szóval volt ebben egy közös gondolkodás, és megvolt az egymásra támaszkodás lehetôsége - ezt jó volt megtapasztalni.

Ami a hátránya például, hogy sokkal jobban elfáradtam ebben az online munkában. Szóval hiába volt az, hogy ügyeleti rendszerben dolgoztunk 8-tól 14-ig, és kétszer voltam az Ambulancián, és keddenként meg csütörtökönként az egyetemről vezettem a stábot vagy éppen csináltam terápiás ülést, tehát hiába volt kevesebb összességében a ledolgozott óraszám, mégis jobban elfáradtam. Szóval másfajta figyelem ez, van egyfajta kiszolgáltatottság. Volt bennem egy olyan érzés, hogy távolabb vannak a páciensek, szóval egy kicsit elérhetetlenebbek, abból a szempontból - persze az lehet, hogy bele lehet ebbe rázódni, de volt ennek azért egy szorongása -, hogy ha valaki bajban van, amikor így online látom, nem tudom azt mondani, hogy akkor most felállunk, és átmegyünk a klinikára, ha most tényleg ennyire rosszul van. Volt ennek azért egy kicsit ilyen szorongása. Lehet, hogy ettől is volt az, hogy így fárasztóbb volt. Ez hátránya szerintem.

Az előny lehet még, hogy az a páciens, aki dolgozik - most a járvány alatt home officeban, amúgy pedig nem home office-ban -, korábban nehezebben tudott eljönni a munkahelyéről, egy online találkozás viszont kevesebb időkiesést jelent. Vagy a külföldi páciensek esetében az jó, hogy ezt mindenki belátja, hogy lehet velük így dolgozni, és kell is velük így dolgozni.

Az ügyeleti rendszerből adódóan sokkal több feladatot kellett ellátnunk: voltunk ketten, terápiát csináltunk, telefonokat kellett felvenni, jöttek metadonért - szóval sokkal pörgősebb volt az az idő, amit az Ambulancián töltöttünk, mégha rövidebb is volt.

- Mondtad, hogy az online terápia kapcsán fontos volt, hogy biztonságos platformot tudjatok használni. Milyen platformok voltak azok, amiket biztonságosnak itéltetek?

- Egyik home office-ban dolgozó kollégánk járt ennek jobban utána. A Zoom-ot használták sokan, de aztán jöttek azok a hírek, hogy nem biztos, hogy annyira biztonságos, és akkor a BlueJeans-t választottuk. Ez egy előfizetéses applikáció, szóval ez anyagi befektetés. Eleinte ehhez is kellett rugalmasság, mert egyrészt nem minden páciensnek volt az elején Skype-ja vagy Messenger-e, másrészt pedig volt, akit csak ezen a módon lehetett elérni. Aztán próbáltuk egy egységes platformra terelni őket. Még az MBT-seket is úgy értük el az első időszakban, ahogy tudtuk, de eleinte, amikor még nem a BlueJeans-en beszélgettünk, még nem vettünk fel 
videót. Mióta átálltunk erre a programra, azóta rögzítjük videóra a beszélgetéseket. Ebben intézményi szinten még nem vagyunk teljesen egységesek, de én mostanra átállítottam már szinte minden pácienst erre a platformra, nem csak az MBT-sekkel használom. Ez a jövőt tekintve szerintem fontos lehet, hogy akár intézményi szinten legyen egy egységes online platform, amit tudunk használni, amiben, mint itt, a Teams-ben ${ }^{3}$ is, sokféle dolgot meg lehet oldani. Terápiát is, de lehet fájlokat is feltölteni. Szerintem ez lényeges, hogy ez meg tudjon maradni, vagy például az online bejelentkezés, az online konzultáció, terápia is tovább tudjon maradni, mert ez müködőképes, bizonyos keretekkel, limitációkkal.

- Ez egy pozitív folyománya lehet a járványhelyzetnek, a jövőre nézve bövíti a lehetőségeket.

- Igen, igen. Én gondolkodok fejlesztésen, valami olyan platform kell, ami biztonságos, mindenkinek elérhető itt a rendszeren belül, és akkor azt tudjuk használni, mert valószínűleg lesz erre még szükség.

- Nagyon fontos, érdekes szakmai tapasztalatokat, dilemmákat és megoldásokat osztottál meg ezzel a rendkívüli idöszakkal kapcsolatban. Köszönöm.

\section{Interjú Máté Zsolttal}

- Benneteket az Alternativa Ifjúsági Irodánál és a TÉR Közösségi Szolgálatnál hogy érintett a koronavirus miatt kihirdetett rendkivüli helyzet?

- Ügyeleti rendben müködtünk, heti kettőt volt nyitva az Alternatíva, és heti kettőt a TÉR, félfél napot.

Az Alternatíva egy kvázi megkereső program, mellyel az utolsó másfél évben már egyértelmüen az iskolai színtéren, kollégiumokban és közösségi házakban volt a fö elérési pontunk. Ezt rendkívül súlyosan érintette. Szóba sem került, hogy ez ott folytatódhatna, ezek nyilván teljesen leálltak, a többi szolgáltatás pedig mind átment online színtérre. Ami az intézménybe bejövő embereket illeti, nem volt jellemző már korábban sem, hogy csak úgy az utcáról beestek - az a populáció teljesen eltünt. Inkább szervezett formában érkeztek, kifejezetten konzultációra. Ez is leállt: mindjárt az első héten az INDIT rendszerén belül az volt a hivatalos állásfoglalás, hogy csak nagyon speciális esetekben lehet klienst fogadni. Itt tulajdonképpen másfél hete állt vissza a kliensforgalom a helyszínen, mármint jött be egyáltalán kliens, akit fogadtunk. A járvány alatt a konzultációkat valamennyire próbáltunk online színtérre átrakni. Olyanok nem nagyon voltak egyébként, akik a semmiből jelentkeztek be online, talán ketten. Olyanok maradtak inkább meg, akikkel korábban már elkezdődött a személyes konzultáció, és azt folytattuk az online térben. Én azt látom, hogy országos szinten elég nagy verseny alakult itt ki: nagyon sok kliens ment át az online térbe, így kérdés volt, hogy mik azok a szolgáltatások, amelyeket el tudnak érni. Akinek jó volt a promóciója, vagy az Interneten jobban megtalálták, annál jelentkeztek - ha egyáltalán jelentkeztek a semmiből.

A technológia egyrészről nagyon izgalmas, másrészről azért nehéz ügy. Most is éppen online konzultációm volt, és iszonyatosan visszhangzott. Egy gettófaluban van egy kliens, ő ott valami könyvtárba bemehet, és onnan veszi fel a kapcsolatot - ami még szerencsésebb eset, mert az mégiscsak egy kiemelt tér, ahol el tud szeparálódni. Ha viszont a kliens otthon van, nem tudsz úgy konzultálni, mert rohangál a gyerek és sok egyéb zavaró körülmény előadódhat.

\footnotetext{
${ }^{3}$ Az interjú a Microsoft Teams alkalmazáson keresztül zajlott.
} 


\section{- A kliensnél vagy nálad?}

- A kliensnél. Na jó, nálunk is. Nehéz otthon megoldani, hogy én is konzultáljak, a feleségem is online dolgozzon, és a két gyerek is online tanuljon. Négy emberrel egyáltalán technikailag ezt hogy oldod meg, mondjuk az alsós gyerekek mit csinálnak? Szóval örületes munkaszervezési probléma volt, hogy ki van a gyerekekkel, hogyan lehet közben dolgozni. Nekem úgy vált be az online munka, hogy bejártam ide, az Alterbe. A szakemberekkel még csak elvagy otthonról, meg az online kortárs segítő képzést is otthonról csináltam, de a konzultáció közben, amikor klienssel dolgozol, ott azért jó egy elszeparált tér, ahol nincs zavaró körülmény. Odahaza ezt nem tudtam csinálni.

- A ti klientúrátok egy része, gondolom, nehezen jut számítógéphez...

- Telefonjuk van, most például egy klienssel, aki egy ormánsági faluban lakik, telefonon beszéltem, de az volt a baj, hogy náluk otthon van három gyerek, meg a nagymama. És beszéljünk úgy, hogy ne a gyerekek elött beszéljünk. Egyébként abban a faluban például meg lehetett beszélni az önkormányzattal vagy egy karitatív szervezettel, hogy bemehettek közösségi terekbe. Olyan megoldás is volt egy másik, 180 fős kistelepülésen, hogy amíg a kliens az otthonából online konzultált, addig a gyerek elment valahova - valakivel együtt tanult angolt egy közösségi házban.

Akadt „tragikomikus” eset is. Egy szenvedélybeteg anyáról van szó, aki lerészegedett az otthoni online a konzultáció alatt. Ez is egy olyan eset, amire nem is gondolsz, hogy előfordulhat. Egy órája tartott a konzultáció, és még negyed óra lett volna vissza, amikor azt mondta, hogy elmenne WC-re, és amikor visszatért, leült, még beszéltünk is, majd öt perc után se kép, se hang. Gyógyszert szed, nagyon erős fájdalomcsillapítót, és arra iszik rá - beszélni nem tudott. Mindez sok mindenre utal, például, hogy mit enged meg magának a kliens otthon, ahol azért mégis egy másik szituációban van, mintha személyesen konzultálnánk. Gyakori, hogy a szenvedélybetegek tagadásban vannak, úgyhogy ez egy szakmailag is nagyon érdekes szituáció volt: egész addig tagadásban volt, hárított, „nem, ez a falu rossznyelve”, ő mindenben együttmüködik - igaz, hogy elvették a jogosítványát ittas vezetésért, de szerinte az egyszeri eset volt -, de erre most nem lehetett azt mondani, hogy ezt a falu rossznyelve mondja. Nem volt mit tagadnia. Mondtam is neki, hogy jó, akkor most leállunk, és holnap reggel szeretnék vele beszélni. A munkahelyéről kéretőzött el, mert közmunkásról van szó, ahol tudták, hogy hol van. Most képzeld el a szituációt, hogy ez egy kis falu, és már telefonáltak a gyermekjólétisnek, és közben nekem, hogy részegen ment vissza az addiktológiai konzultációról. Ilyen a valós térben mikor van? Soha.

- Az online konzultációk között volt olyan, ami jobban ment?

- Erre sem mondom azt, hogy rosszul ment, csak azt, hogy egy csomó zavaró tényező van. A legutóbbi klienssel, akivel alig egy órája - az interjú előtt - beszéltem, szerintem nagyon jól ment: ez egy indulatkezelési konzultáció volt. Az is pozitív tapasztalat, hogy a munkahelyek elég rugalmasak voltak, hogy a munkaidőből egy-egy óra szünetet biztosítsanak a klienseinknek konzultációra. Például a most említett kliens feleségével, aki szintén kliensünk, is így történt. Amíg online konzultáltunk vele, addig keresett valami félreeső helyet a munkahelyén, most pedig már visszaállt személyes konzultációra.

Az egyéni online konzultáció, az könnyebb történet, de ha már négy, öt, hat, hét, nyolc embert kellett egy helyre ültetni, az nem ment. A csoport, az sokkal nehezebb, ott már nagyon erős motiváció kell.

- Ha már itt tartunk, emlitetted a kortárs képzést. Az hogy ment? 
- Online, csoportmunkában. Nagyon nehéz ügy volt. Ez egy 9 alkalmas képzés, ebből 5 ment le a valóságban, és még 4 volt vissza a járványhelyzetben. Most vagyunk a végén - szó-szó... Nyolc fös volt a csoport, ebből ketten lemorzsolódtak eleve - hát szenvedünk vele. Én azt látom, hogy az online munka egyéniben tud müködni, de csoportban sokkal nehezebb - bár lehet, hogy ez csak a fiatalok esetében ilyen nehéz ügy. Egyébként izgalmas volt, olyan témát is érintettünk, az önsértést, az öngyilkosságot, az érzelmi megterhelést, ami érdekelte öket, meg érintettek is voltak.

- Mi volt a nehézsége ennek az online csoportos formának?

- Passzívabbak is voltak, meg az összeegyeztetés, az időpontok összeegyeztetése. Skype-on oldottuk meg. Volt olyan, aki azt mondta, hogy ö nem beszél, nem akar, hanem inkább ír. Ott nagyon rugalmasnak kellett lennünk. Érdekes, hogy van, akinél kialakul az, hogy nem szólal meg. Tök jól müködött élöben, az online térben meg valahogy olyan szintü lett a szorongása, hogy nem szólalt meg. Azt láttuk, hogy a Covid-időszakban olyan állapotba került, hogy segítségre van szüksége.

A szervezés nagyon nehéz ügy volt, pont akkor mentünk át online-ba, amikor már kezdődött az érettségi időszak. Volt, aki írta, hogy nem tud online részt venni egyáltalán, mert a mobilnetkerete másra elmegy, és nem tud többet fent lenni az online térben. És a többieket is nehéz volt összehangolni, hogy kinek melyik nap jó. Volt, aki azt mondta, hogy most érettségi van, aztán felvételi, és most nem tud jönni. Volt, akinek akkor volt órája. Nem is akartunk túl offenzívek lenni: kamaszok, meg elmarad a ballagás - nem akartuk annyira eröltetni. Egyszerre akartunk megértőek lenni, meg vinni is a programot, és ez így nehéz téma, hogy hogyan erőlteted magad bele ebbe a szituációba.

Tulajdonképpen, ha úgy veszed, akkor az egész világnak egy évszak eltünt az életéből. Főleg a kamaszoknál, 3-4 év a serdülőkor - akkor legyél szerelmes stb. -, és ha ebből a 3-4 évből egy évszakot kiveszünk, az agyon lett csapva. A kamasznak a legfontosabbak a barátai, a haverjai, és most se barátok nem voltak, se testi kontaktus, ölelés, szóval kortárs szerelem. Ezek olyan dolgok, amelyekre nagyon tekintettel kell lennünk szerintem. Az oktatás nem volt tekintettel sok helyen ezekre a dolgokra, de mi nem akartunk annyira szemellenzősök lenni.

- És mi történt a másik szolgáltatásotokban, a TÉR-ben a járványhelyzet idöszakában?

- Érdekes, hogy míg az Alterben teljesen leálltak a helyszíni konzultációk, kint a TÉR-ben, a romatelepen viszonylagosan megmaradtak - ott nem szünt meg a személyes kliensforgalmunk. Egy furcsa helyzet állt elö, mert ott egy másik szolgálat, amely addig kint volt a terepen, azonnal ajtót-ablakot bezárt, és végül mi maradtunk az egyetlen nyitva maradó szervezet; ott a gyermekjólét sem ment ki. Az első egy hónapban volt egy teljes leállás, mi viszont heti két alkalommal fél napokat müködtünk, és abban az időszakban jöttek is hozzánk krízissel.

- Milyen jellegüekkel?

- Megélhetési gondokkal. Illetve olyan problémákkal is jöttek, hogy - mivel leálltak a gondozók, az orvosi ellátás - hogy lehet időpontot kérni, mit hogyan kell intézni. Ezek főleg telefonos ügyintézések voltak. Olyan is volt, hogy az ambulanciával próbáltak kapcsolatot tartani: Jánosnak [Dr. Szemelyácz János, az INDIT vezetője] van egy-két betege kint, és jöttek időpont-megbeszélésre, megtudni, mi hogy lesz, meg egy kis konzultációra: akkoriban nem mentek be hozzá a Drogambulanciára, hanem kijöttek a TÉR-be, és onnan telefonon konzultáltak.

- Tehát a TÉR-ben volt személyes kontakt. Volt valamilyen biztonsági óvintézkedés? 
- Ez nagyon érdekes, mert ez egy munkajogi kérdés is. Azt a pánikot, amikor először bezártak az egészségügyi intézmények egyik pillanatról a másikra, és a szociális intézmények még itt álltak, akkor hogyan tovább, hogy csináljuk meg az ügyeleti rendszert! Csak úgy tudtuk megcsinálni, hogy voltak olyan emberek, akik korábban önkénteskedtek: az Alterba ügyeletbe jövő önkéntes segített kint a TÉR-ben is (később már külön eseti szerződéssel) - különben nem tudtuk volna csinálni. Vannak kollégák, akiknek gyerekeik vannak - tegyük hozzá, hogy vannak olyan területek, ahonnan a gyerekes szülőket egyből hazaküldték. Vagy van súlyos betegségből felépült kollégánk, aki még utógondozásra, felülvizsgálatra jár: éppen akkor küldték el a vizsgálatról - „Ne haragudjon, nem tudjuk Önt fogadni.” -, én meg mondjam neki, hogy heti kétszer ügyeletet tartunk. Volt olyan kollégám, aki bepánikolt, és azt mondta, hogy teljesen le kell állni, és ezt mi hogy gondoljuk. Védőfelszerelés szinte nulla. Bár nekünk még maradtak ilyen olcsó, 30 forintos papíralapú maszkjaink, amik semmit nem érnek hivatalosan (utána ezeket már 500-700 forintos áron árulták). Ezt egyszer használod, és ki kéne dobni. Próbáltunk beszerezni védőeszközöket, volt, amikor a külföldröl rendelt felszerelést leállították a határon - nem tudtál hozzájutni. Központi védőfelszerelést nem kaptunk, csak amit János a közalapítvány pénzén megrendelt. Ez mondjuk újabb kérdéseket vet fel.

- Végül mi lett, hogy döntöttétek el, hogy van-e olyan, akit felmentetek a munkavégzés alól?

- Képzeld, én, mint munkáltató, mit mondjak a kollégáknak? Van egy olyan kolléga, akinek várandós a felesége - és jöjjön be úgy, hogy semmit nem tudunk arról, hogy ez a vírus hogy müködik. Ezt az apukát mentettük fel teljesen, a többiek pedig jöttek ügyeleti rendszerben. De ha azt mondja az egyik munkavállalóm, hogy „Ne haragudj, nem.”, akkor mit mondok neki?

Kérdés, hogy tudom-e biztosítani legalább a minimálfeltételeket. Jött egy email az egészségügyi területről, hogy ott milyen minimálfeltételeket javasolnak. Nahát, nálunk az a betarthatatlan kategória, és akkor nem beszéltem a többi szociális ellátásról. Az volt leírva, hogy negyedórás találkozás legyen a maximum, nyitott ablaknál - de ha lehet, akkor inkább szabad térben legyetek, 2 méteres távolságban -, úgy, hogy mindenkin maszk van (a kliensnek te adsz), rajtad kesztyü, és negyed óra után elküldöd. Az orvosi ajánlások azt mondták, hogy ami biztonságot jelent számodra, az az 5-ös típusú maszk - mi sokáig 2-est nem tudtunk venni, csak most, a vége felé, hogy el tudjuk kezdeni az utcai munkát hivatalosan. Most 2-es fokozatút már tudsz kapni. Az utcai munkásoknak vettem egy-egy maszkot - négyen csináljuk az utcai munkát -, meg a bent lévőknek egy-egy gyengébb fokozatút, vagyis összesen hatot, vettem egy-egy védőszemüveget, mert az is fertőzhet, ha a szemedet piszkálod, és kézfertőtlenítőt. Azt tudom, hogy 20 ezer forintot hagytam ott, ami a teljes ellátmányunknak az egyötöde. De ha igazán akarod, akkor a maszkból 5-öset kellene adni, és nem 2-eset, de legalább 3-asat. A komolyabbnak viszont már darabja 20 ezer.

Persze, ha garantálnod kell a munkavállalód biztonságát, azt teljes mértékben nem tudod megtenni. És ha valaki megbetegszik, akkor téged vesznek elő a munkahelyen? - Egyáltalán nem is bizonyítható, hogy hol fertőződött meg valaki. Ez az egész egy lehetetlen helyzet.

- Mondtad, hogy bent az intézményben folytatódtak a kliensekkel a személyes találkozások. Az utcai munkával kapcsolatban viszont az elöbb az „újrakezdést” emlitetted. - Ezek szerint az utcai munka leállt a járványhelyzet alatt.

- Terepre nem mentünk ki, az utcai munkánkat teljesen leállítottuk. Volt, ahol védőfelszerelés nélkül kimentek terepre szociális ellátásba. Elhűlve láttam, hogy valahol Dél-Magyarországon, addiktológiában dolgozók kimentek terepre. Ha voltak is védőeszközeik, ezek valódi védőeszközök voltak-e? 
Tulajdonképpen az is óriási gond volt, hogy nem nagyon jöttek iránymutatások. Eleinte valamennyire az egészségügyhöz próbáltunk igazodni, ahhoz az e-mailben jött útmutatóhoz. A szociális területről nagyon későn jöttek állásfoglalások, és azok egyértelműen a terepmunka tilalmát írták elö.

Ugyanakkor az egy etikai kérdés is, hogy az utcai munkában kvázi elengedtük a klienseink kezét. Utólag tudtuk meg, hogy ők, a prostituált klienseink sem nagyon voltak kint az utcán az első egy hónapban. De aztán kimentek; akiknek már egy hónap után megélhetési gondjaik voltak, kénytelenek voltak kint lenni. Náluk óriási volt a kockázat. Ha az van, mint Olaszországban, akkor nem is tudom, mi lett volna. Óriási szerencsénk volt, hogy az elején a fertőzés nagyon el lett szeparálva, de ez az egész sokkal durvább is lehetett volna. Szóval mindez a jövőre nézve is egy óriási kérdés. Mi lesz, ha újra ilyen helyzetbe kerülünk?

- Erre van valami víziótok az ellátáson belül? Valami terv?

Azért sok tanulsága volt ennek a mostani helyzetnek. Én folyamatosan azt nézem, hogy mikor lesz olcsóbb, hogy mikor lehet beszerezni egyáltalán védőeszközöket. Lehet munkát végezni, csak megfelelö védőeszköz kell.

- Többször elöjött a különbség az egészségügyi és a szociális szféra között. Erröl mit gondolsz? - Az egészségügy és a szociális szféra köszönőviszonyban sincs. Ebböl a szempontból a rendkívüli helyzet nagyon komoly méltányossági kérdéseket vetett fel. Van, ahol szinte totálisan leálltak, egészségügyi vonalon például maximum annyit mondtak, hogy ,jöjjön be, kap egy injekciót", aztán viszontlátásra. Mi meg fogadhattuk a klienseket. Szóval az egészségügy sokkal jobban leállt. Van valaki, aki az egészségügyben dolgozott, és nulla páciensforgalma volt, és van a szociális munkás, aki heti két nap bent volt, és találkozott emberekkel: az egyiket kitüntetik 500 ezer forinttal, a másik meg egy forintot sem kap. Mi az INDIT-ben integrált intézményként müködünk, ahol van egészségügyi rész, meg van szociális rész egy rendszeren belül, és ez feszültséget okoz, hogy teljesen más helyzetben vannak a szociális dolgozók, mint az egészségügyisek. Ez is egy etikai kérdés. Ez végül is diszkrimináció az egészségügyi és a szociális ellátórendszer között.

- Igen, ez bizonyára egy komoly társadalmi vitát igénylö kérdés. Érdekelne még, hogy az elmúlt hónapok rendkívüli körülményeinek volt-e nálatok valamilyen pozitiv hozadéka.

- Az, hogy az Alternatívában az iskolai színtér teljesen megszünt, eléggé pótolhatatlan, ezzel viszont valamennyi időnk is felszabadult. Amire a leállás alatt nagyon sok energiát fordítottunk, hogy az Interneten cikkeket jelentettünk meg, és dolgoztunk a háttérben online anyagokon. Most elkészült ez alatt a Covid-időszak alatt az önsértésről egy szóróanyagunk online meg papír formátumban is. Megjelent egy anyag az öngyilkosságról is. Nagyon sokat a blogunkon, a Velocigiraffe-én osztunk meg, de volt, ami felkerült az Index2-re. Az önbecsülésről szóló anyagunk nagyon praktikus, azt is sokan nézték. Volt egy anyag a beavatási rítusok meg az alkoholfogyasztás kapcsolatáról, annak az olvasottsága volt egy ezres. A gyereknevelés, jutalmazás, büntetés, fegyelmezés kérdéséről is készült egy hosszú cikk. Tavaly indult, az utolsó két darabja most készült el, az is felment a netre. Ezek mind edukációs anyagok, amik nagyon praktikusak, és háttérmunkában készültek, közülük sok a krízisidőszakban.

- Emlitetted, hogy az online térben egyfajta verseny alakult ki a szolgáltatók között - ez pedig fejlödést hozhat.

- Igazából itt az emberben két dolog vívódik, az egyik az, hogy figyeld a többieket, mert az lehet inspiráló, meg foglalkozz a saját dolgaiddal, csináld, szerezz tapasztalatokat. Mi ezt a fajta 
munkát már korábban is elkezdtük - azt mondhatom, hogy a helyzet nem ért minket felkészületlenül. A blogunk megvolt, amit már korábban is használtunk, volt felületünk.

Az online tartalmak létrehozása izgalmas munka, de az látszik, hogy ez nagyon sok szempontból pénz kérdése is. Ezt reklámozni kell. Mondok egy vicces történetet: A [...]-i egyetemen meghívott tanár vagyok, és kaptam dolgozatokat prevenciós témából. Azt vettem észre, hogy volt olyan, amikor a csoportnak legalább a fele ártalmas programot állított össze. Sületlenségek voltak. És akkor elkezdtem utánanézni a neten, és kiderült, hogy egy pénzesebb szervezet anyagából volt, abból állították ezt össze. Mert ők nyilván perkálják a pénzt, hogy a keresőoldalakon előbb rakják fel őket. Végtelenül egyszerü a történet.

- Az online térben könnyebb megjelenni, nem kell intézményi háttér feltétlenül, tehát megjelenhetsz akármilyen bloggal, hozzáértés nélkül, és ott megoszthatsz téves dolgokat, amit ezrek, tíz-vagy százezrek fognak elhinni.

- Most ezen dolgozunk például, hogy hivatalosabbá tegyük a blogunkat, hogy megmutassuk, mi a háttere. Nekünk ez fontos a médiatudatosság szempontjából. Eddig inkább újságok által müködtetett site-oknál volt jellemző, hogy megadják, kik írják, ki a fenntartó. Tehát ez ma még egy fura dolog, hogy egy ingyenes blogra ilyen adatok felkerülnek - nekünk maga a tartalomelöállítás időbe kerül, meg volt, amikor pályáztunk fotózásra, meg cd-re és ilyesmikre, de maga a blog müködtetése, az nulla forint. Mégis fontosnak tartjuk feltenni ezeket az adatokat, és amennyire lehet, tudományosak vagyunk. Persze ebben a médiatérben egyensúlyoznod kell a tudományoság és az olvashatóság, közérthetőség között. Azért bármilyen cikket teszünk fel, mindig ott vannak a végén a hivatkozások, a tudományos alapok, hogy honnan van, tehát az objektív információk. Arra is figyelnünk kell, hogy az az igazán oké, ha tartalomelőállító vagy. Nem innen-onnan előhalászott gagyi fotókkal dolgozunk - és most nem a Fotrepanra gondolok, abban mint archívumban végül is te kutakodsz, az ilyen szempontból oké; de az összes többit mi csináljuk, a fotókat, meg a szöveges anyagokat nincsenek másodközléseink. Ez viszont időigényes, meg sokszor pénzigényes.

Ez egy jó történet, kicsit átláthatóvá teszi a szakmai munkánkat, hogy mivel foglalkozunk. Abszolút pozitív pszichológia. Szinte minden cikkünkben van praktikus dolog: nem csak elmélkedni akarunk, hanem beleteszünk letölthető formátumú anyagokat, ötlettárat, hétköznapi tanácsokat, amiket lehet használni. A krízis alatt több idö jutott erre, a három hónap alatt hat bejegyzésünk jelent meg, azaz kéthetente egy. Az olyan, mintha cikket írnál, és az jelenne meg. Ezekben iszonyú sok munka van, több hetes rákészülés, szakirodalmak feldolgozása, ilyesmi. Itt azért kiállsz a nagyközönség elé; ha ezer ember olvas, vagy csak ötszáz is, jóval alaposabban meg kell nézni, hogy amit leírsz, az hogy van. Sokszor több emberhez jutsz el így, mint ha írsz egy könyvet. Ilyen szempontból ez egy felelősség is.

- A krízishelyzetet tehát az online tartalomelöállitás terén elönyötökre tudtátok fordítani. Köszönöm az interjút, sok fontos dilemmát, tapasztalatot osztottál meg. 